\title{
Pengetahuan, Sikap dan Persepsi Petugas Gawat Darurat Terhadap Kesalahan Medik
}

\author{
Refi Fitri Hamdani Nasution*
}

\begin{abstract}
Abstrak
Kesalahan medik serius paling sering terjadi di intensive care unit, ruang operasi, dan unit gawat darurat. Tujuan penelitian ini mendapat informasi tentang pengetahuan, sikap, dan persepsi tenaga kesehatan terhadap kesalahan medik. Penelitian dilakukan terhadap manajer, kepala seksi, kepala ruangan, ketua kelompok perawat, dokter dan perawat pelaksana. Metode yang digunakan adalah metode kualitatif meliputi wawancara mendalam, observasi, dan telaah dokumen. Metode analisis yang digunakan adalah analisis konten yg membandingkan hasil penelitian dengan teori. Ditemukan bahwa pengetahuan, sikap, dan persepsi tenaga kesehatan cukup baik, tetapi belum diikuti tindakan, sarana prasarana dan pengawasan yang memadai. Sistem rujukan pasien yang kurang baik menyulitkan keluarga pasien. Kesalahan medik dipengaruhi oleh kasus sulit, pasien banyak dan tindakan tergesa-gesa. Sumber kesalahan medik adalah manusia, komunikasi, pasien. Keterampilan SDM dan kondisi fasilitas telah memadai. Namun, ruangan yang belum memadai dinilai sebagai sumber kesalahan medis. Selain itu, sikap antispasi atasan terhadap kesalahan medik kurang memadai. Untuk memperkecil kesalahan medik yang dilakukan upaya-upaya pelatihan, refreshing keilmuan, kolaborasi sesama tim, perbaikan komunikasi, dan mengikuti SOP.
\end{abstract}

Kata kunci : Kesalahan medik, unit gawat darurat, pengetahuan, sikap, tenaga medis

\begin{abstract}
Medical error is known to occur mostly in the intensive care unit, operation room, and emergency unit. The objective of this study is to obtain information on knowledge, attitude, and perception of health workers on medical error. Study was conducted to manager, head of section, head of room, head of nursing team, doctors, and nurse. Qualitative method was employed including in-depth interview, observation, and document review. Analysis was conducted using content analysis that compare study results with theory. The study found that knowledge, attitude, and perception are relatively good, but has not been followed by appropriate action and not supported by sufficient facilities and monitoring system. Not very good referral system was an obstacle for patient's family. Medical error was infleunced to happen by the presence of difficult cases, big number of patients, and in hurry action. The source of medical error was human factor, communication, and patient. Insufficiency or less equipped room was also perceived as source of medical error. Moreover, the attitude of management regarding medical error was not really appropriate. To minimize medical error, it is necessary to conduct trainings, refreshing course, collaboration between teams, communication improvement, and SOP compliance.
\end{abstract}

Key words : Medical error, emergency unit, knowledge, attitude, health workers 
Hampir setiap tindakan medik berpotensi risiko yang dibuktikan dari laporan IOM (Institute of Medicine). ${ }^{1}$ Setiap tahun di Amerika Serikat, sekitar 48.000 100.000 pasien meninggal akibat kesalahan medik di berbagai pusat pelayanan kesehatan. ${ }^{2}$ Data pasti kesalahan medik di Indonesia sulit diperoleh, karena sebagian tidak dikenali, dianggap biasa, atau tidak dicatat. Pengetahuan dan kemampuan yang kurang mengenal serta sikap takut pada atasan menyebabkan insiden yang terjadi tidak dicatat dan dilaporkan. Berdasarkan beberapa studi dalam laporan IOM diketahui bahwa, kesalahan medik dengan konsekuensi serius paling sering terjadi di ICU (Intensive Care Unit), ruang operasi, dan unit gawat darurat. ${ }^{3-6}$

Dalam penerapan program keselamatan pasien di Rumah Sakit "X", diperlukan pemahaman tentang keselamatan pasien khususnya kesalahan medik. Pengelolaan dan antisipasi kesalahan medik di rumah sakit harus ditunjang oleh pengetahuan, sikap, dan persepsi tenaga kesehatan tentang kesalahan medik. Dengan pemahaman tenaga kesehatan yang baik tentang kesalahan medik, diharapkan menunjang keberhasilan program keselamatan pasien. Oleh sebab itu, pemahaman kesalahan medik para tenaga kesehatan perlu penelitian tentang pengetahuan, sikap, dan persepsi tenaga kesehatan terhadap keselamatan pasien.

Penelitian ini bertujuan mendapatkan informasi tentang pengetahuan, sikap, dan persepsi tenaga kesehatan di UGD RS "X" terhadap kesalahan medik. Tujuan khusus mengetahui pengetahuan, sikap, dan persepsi tenaga kesehatan terhadap jenis, edik, medik, dan upaya pencegahannya.

\section{Metode}

Penelitian dilakukan terhadap tenaga kesehatan yang bertugas di unit UGD menggunakan metode kualitatif. Pemilihan sampel dilakukan berdasarkan purposive (non probability). Prinsip pengambilan sampel berdasarkan kesesuaian (appropriateness). Sampel dipilih berdasarkan pengetahuan yang dimiliki dan berkaitan dengan topik penelitian serta kecukupan (adequacy), jumlah sampel tidak menjadi faktor penentu utama tetapi lebih mementingkan kelengkapan data. Berdasarkan prinsip tersebut, maka sampel informan yang dipilih adalah 10 orang yang terdiri dari: manajer, kepala seksi, kepala ruangan, ketua kelompok perawat, dokter ataupun perawat pelaksana yang bekerja di UGD RS "X".

Sumber data adalah data primer yang didapatkan dari hasil wawancara mendalam dan observasi serta data sekunder yang didapatkan dari telaah dokumen yang berkaitan dengan kesalahan medik. Instrumen yang digunakan dalam pengumpulan data adalah kuesioner sebagai pertanyaan terbuka untuk mendapatkan informasi mendalam tentang pengetahuan, sikap, dan persepsi infor- man terhadap kesalahan medik. Observasi dilakukan peneliti mengacu Standar Operasional Prosedur (SOP) di unit tersebut. Observasi dilakukan untuk melihat tindakan para informan dan mengumpulkan informasi lain yang terkait tujuan penelitian. Observasi dilakukan dengan melihat langsung peralatan dan protokol yang tersedia, kondisi ruangan, dan pelaksanaan pelayanan asuhan klinis di Unit Gawat Darurat. Telaah dokumen dilakukan dengan melihat dokumen yang tersedia di unit tersebut yang berkaitan dengan kesalahan medik. Data yang sudah terkumpul diolah secara manual dengan membuat transkrip data, serta disusun dalam bentuk matriks dan dianalisis dengan metode analisis isi (content analysis).

\section{Hasil \\ Pengetahuan}

Didapatkan bahwa sebagian informan telah memahami pengertian kesalahan medik bahwa kesalahan medik adalah kesalahan akibat salah mengambil tindakan dan penanganan, kesalahan prosedur yang berakibat fatal atau nyaris fatal pada pasien. Pengertian tentang kesalahan medik beragam, tapi inti dan maknanya hampir sama. Pada penelitian ini, pengertian yang digunakan berasal dari Komite Keselamatan Pasien Rumah Sakit. ${ }^{7}$ Kesalahan medik adalah kesalahan yang terjadi dalam proses asuhan medis yang mengakibatkan atau berpotensi mengakibatkan cidera pada pasien. Kesalahan gagal melaksanakan suatu rencana secara penuh atau menggunakan rencana pencapai tujuan, dapat akibat melaksanakan tindakan (comission) atau tidak mengambil tindakan yang seharusnya (omission). Sebagian besar informan kurang mengerti tipe kesalahan medik karena belum pernah mendapatkan informasi tersebut. Terbukti sebagian informan bertanya dan mengungkapkan informasi yang tidak memadai.

Semua informan mengetahui secara baik upaya yang dapat dilakukan untuk mencegah kesalahan medik, seperti program patient safety, KIE, diskusi kasus, laporan jaga dokter, penilaian kinerja. Salah satu informan mengatakan bahwa peningkatan kompetensi tim kesehatan harus sesuai dengan kondisi dan keadaan. Informan lain mengatakan bahwa dokumen setiap tindakan yang dikomunikasikan pada tenaga kesehatan yang bertugas tentang kondisi pasien merupakan salah satu upaya pencegahan kesalahan medik.

\section{Sikap}

Informan berpandangan bahwa kesalahan akibat melakukan tindakan ataupun melakukan tindakan yang keliru merupakan hal yang wajar jika kesalahan tersebut tidak terulang kembali. Ada juga yang menyatakan bahwa kesalahan itu bukan merupakan hal yang harus ditutup-tutupi tetapi kesalahan itu merupakan pembela- 
jaran bagaimana mengantisipasi, agar kesalahan yang sama tidak terulang lagi. Informan berpandangan bahwa setiap tindakan yang dilakukan mengikuti rangkaian prosesnya akan berisiko kecil sekali untuk terjadi kesalahan medik. Berdasarkan hasil observasi, peneliti menemukan paradoks antara pernyataan yang disampaikan dengan tindakan yang dilakukan informan. Peneliti melihat, beberapa kali tindakan dilakukan lebih dulu sebelum pemeriksaan penunjang atau menegakkan diagnosa tanpa didahului dengan anamnesa yang akurat dan teliti. Peneliti juga mendapatkan informasi akibat kesalahan diagnosa suspect flu burung didiagnosa demam berdarah mengakibatkan rumah sakit mendapat tuntutan bukan dari keluarga yang mengalami kesalahan mendiagnosa, tetapi dari keluarga pasien yang ditempatkan sekamar dengan penderita flu burung tersebut.

Permasalahan yang sering dikaitkan dengan pelayanan klinis di Unit Gawat Darurat adalah pemenuhan standar pelayanan kegawatdaruratan medis, baik standar pelayanan, standar profesi, standar prosedur operasional, standar kompetensi tenaga medis, dan standar peralatan. Informan berpendapat bahwa, dari segi sumber daya manusia dan peralatan sudah baik, hanya ruangan yang kurang memadai. Menurut informan, kesalahan medik sebenarnya dapat membawa dampak negatif dan positif terhadap pemberi pelayanan. Dampak positif dapat dilihat dari pernyataan seperti, membangun kesadaran untuk bertindak lebih hati-hati, belajar dari kesalahan agar kesalahan yang sama tidak terulang lagi. Pada dasarnya, secara tidak langsung meningkatkan pengetahuan dan pemahaman petugas pemberi pelayanan terhadap kondisi tertentu. Sebagian informan pelaksana menyatakan kurang setuju dengan sikap yang diambil oleh pemimpin di Unit Gawat Darurat untuk mencegah kesalahan medik di ruangan tersebut dan kebutuhan pengawasan terhadap kebijakan yang sudah dijalankan rumah sakit.

\section{Persepsi}

Berdasarkan hasil penelitian tentang persepsi tenaga kesehatan, informan mengatakan bahwa kesalahan melakukan tindakan disebabkan kasus-kasus sulit dan tindakan yang diberikan harus cepat serta banyaknya pasien. Salah satu informan mengatakan bahwa, di Unit Gawat Darurat sering terjadi dokter atau perawat lupa untuk melakukan follow up. Ada juga informan yang berpendapat bahwa kesalahan dalam diagnosa bukan dikarenakan keterlambatan menegakkan diagnosa, tapi karena dalam mendiagnosa harus melalui beberapa prosedur. Ada juga jawaban yang menarik yang disampaikan informan, bahwa kecepatan mengambil tindakan tergantung pada tipe dokter yang bertugas jaga pada saat itu. Pernyataan tersebut mengisyaratkan masih terdapatnya kesenjangan komunikasi antara dokter dan perawat yang bertugas di unit tersebut.

Berdasarkan hasil wawancara, sebagian besar informan menyatakan bahwa faktor sumber daya manusia yang merupakan faktor utama terjadinya kesalahan medik di UGD tersebut. Selain masalah human error, kesalahan medik menurut sebagian informan sering terjadi dikarenakan pasien ataupun keluarga pasien. Kesalahan bisa terjadi karena pasien kurang memberikan informasi yang menyebabkan miskomunikasi dan karena faktor biaya. Hal ini juga dibuktikan dengan hasil observasi peneliti yang menemukan bahwa hambatan komunikasi antara petugas Unit Gawat Darurat dengan pasien atau keluarga pasien selain karena masalah biaya juga diakibatkan adanya perbedaan pemahaman kondisi pasien dan pemahaman sistem rujukan medis di rumah sakit, walaupun pasien ataupun keluarga pasien telah mendapatkan penjelasan oleh petugas Unit Gawat Darurat. Selain itu, hambatan komunikasi juga disebabkan kondisi di Unit Gawat Darurat dengan kondisi kontak antara pasien dan tenaga medis bersifat singkat dan kadang sulit dilakukan. Ada juga informan yang mengatakan bahwa kesalahan medik secara tidak langsung membawa dampak yang positif terhadap petugas di Unit Gawat Darurat, karena dapat meningkatkan pelayanan dengan sikap yang 'aware' atau lebih hatihati dalam memberikan pelayanan sehingga dapat terhindar dari kesalahan yang sama.

Menurut informan upaya pencegahan yang seharusnya dilakukan untuk mencegah terjadinya kesalahan medik di ruangan Unit Gawat Darurat dengan melakukan refreshing keilmuan secara rutin, memperbaiki komunikasi dan kolaborasi antar sesama tim. Berdasarkan hasil observasi peneliti menemukan baik lisan dan tulisan antarpetugas Unit Gawat Darurat RS "X" kurang memadai.

\section{Pembahasan}

Menurut Leape, ${ }^{8}$ kesalahan medik dapat digolongkan berdasarkan proses kejadian yang meliputi kesalahan diagnostik, terapi, preventif, dan lain-lain, berupa kegagalan berkomunikasi, kegagalan alat, dan kegagalan sistem. Sebagian besar informan mengatakan bahwa sumber daya manusia merupakan sumber-sumber terjadinya kesalahan medik. Sebagian informan mengatakan bahwa sumber terjadinya kesalahan medik bisa terjadi dikarenakan kurangnya fasilitas, ataupun keterbatasan ruangan. Ada juga yang menjawab bahwa sumber kesalahan itu dapat terjadi bukan saja dikarenakan dari sumber daya manusia tapi juga karena faktor pasiennya. Dapat disimpulkan bahwa kesalahan medik bukan hanya berdampak pada perawatan yang lebih lama, biaya yang lebih besar, kecacatan, dan kematian tapi lebih jauh berpotensi merugikan rumah sakit secara finansial, reputasi dan image. 
Sikap menghindari kesalahan medik dapat diikuti perubahan budaya organisasi dimana setiap petugas rumah sakit memandang kesalahan bukan merupakan faktor kesengajaan, organisasi harus membangun budaya tidak mencari-cari kesalahan pada seseorang (no blame culture) sehingga kesalahan dapat diminimalisasikan dari hasil laporan petugas terhadap kesalahan yang dilakukannya. Ternyata kesalahan diagnosa disebabkan oleh gejala ataupun gambaran penyakit flu burung yang hampir sama dengan penyakit lain, sehingga sulit untuk mendiagnosa dengan tepat. Oleh karena itu, peneliti berpendapat, kesalahan dalam mendiagnosa bukan saja akibat tidak diikutinya rangkaian proses yang sistematis dalam menegakkan diagnosa, tetapi dapat juga karena kasus sulit yang jarang dijumpai, sehingga dokter kurang terlatih menghadapi kasus tersebut.

Namun demikian, berdasarkan observasi peneliti menemukan bahwa ada kesenjangan informasi antara yang disampaikan oleh informan dengan kenyataan sebenarnya mengenai fasilitas yang terdapat di unit tersebut. Peneliti mendapati bahwa di ruangan tersebut belum memiliki fasilitas yang lengkap. Pada suatu kejadian, pasien datang dalam keadaan tidak sadar dan membutuhkan alat monitor, namun tidak bisa segera ditindaklanjuti karena harus menunggu alat datang dari ICU (Intensive Care Unit). Selain itu, peneliti menemukan bahwa ruangan di unit tersebut terbatas, hal ini dapat dilihat dari tidak adanya ruangan observasi, ruangan resusitasi dan sebagainya, walaupun ada sistem triage tapi tidak dimanfaatkan secara maksimal. Ada juga 1 informan yang berpendapat bahwa di unit tersebut meskipun secara keseluruhan sudah memiliki sumber daya manusia yang terampil, tetapi ada juga SDM yang tidak kompeten yang bertugas di unit tersebut. Maksud tenaga yang tidak kompeten disini bukan hanya ditinjau dari pengetahuan yang meliputi kompetensi intelektual, tapi harus dibarengi juga dengan keterampilan, kecerdasan memecahkan masalah, dan mengambil tindakan yang cepat dan tepat pada saat menangani pasien

Hasil telaah dokumen peneliti menemukan bahwa kebijakan rumah sakit mengantisipasi kesalahan medik salah satunya dengan laporan insiden. Namun, dokumen pelaporan sendiri tidak ditemukan oleh peneliti di ruangan tersebut, padahal kebijakan dan sosialisasi sudah dilakukan sejak bulan Agustus tahun 2006. Hal ini merupakan salah satu contoh kurangnya pengawasan terhadap kebijakan tersebut. Selain itu, perlunya komitmen dari rumah sakit untuk memberikan jaminan terhadap pelapor agar kebijakan tersebut dapat berjalan dengan baik. Menurut Institute of Medicine, ${ }^{1}$ setiap tindakan medik yang dilaksanakan tetapi tidak sesuai dengan rencana atau prosedur sudah dianggap kesalahan medik. Disisi lain melakukan upaya medik melalui prosedur yang keliru juga dianggap sebagai kesalahan medik.
Berdasarkan hasil observasi, selain masalah komunikasi antara pasien dan petugas, peneliti mengidentifikasi bahwa masalah rujukan berpotensial menyebabkan kesalahan medik. Hal ini dikarenakan UGD RS "X" tidak membantu untuk melakukan rujukan ke rumah sakit lain, bagi pasien-pasien kronis yang tidak mendapatkan tempat perawatan di RS "X”, sehingga keluarga pasien mengalami kesulitan untuk menghubungi rumah sakit lain. Akibatnya, pasien kronik yang harusnya mendapatkan pelayanan di ICU sesuai kondisinya, akhirnya di rawat di UGD dengan perawatan seadanya.

Berdasarkan hasil telaah dokumen, peneliti menemukan bahwa dokter sering tidak menuliskan instruksi pada catatan dokter, sehingga menimbulkan miskomunikasi antara dokter dan perawat. Selain itu, ada 2 informan yang mengatakan bahwa salah satu upaya yang dapat dilakukan untuk mencegah kesalahan medik adalah dengan meningkatkan "sense of crisis" dari setiap dokter ataupun perawat. Pernyaatan tersebut mengisyaratkan bahwa masalah yang berkaitan dengan tindakan medik bersifat multifaceted, yang tidak saja dipengaruhi keterampilan klinis (clinical skills), penguasaan terhadap pengetahuan terkini (up-dated knowledge), tetapi harus dibarengi dengan kewaspadaan klinis (clinical awareness), dan tingkat kepedulian yang tinggi dari para tenaga kesehatan sehingga dapat memberikan penatalaksanaan serta pengelolaan yang tepat pada pasien.

\section{Kesimpulan}

Secara umum sebagian besar informan sudah mengetahui dan memahami pengertian kesalahan medik, sumber-sumber kesalahan medik, dampak kesalahan medik, dan upaya pencegahan kesalahan medik, sedangkan tipe-tipe kesalahan medik informan belum mengetahuinya. Sikap para informan tentang pengertian kesalahan medik, tipe-tipe kesalahan, sumber-sumber kesalahan medik, dampak kesalahan medik, dan upaya pencegahan kesalahan medik menunjukkan sikap positif, namun belum dibarengi dengan tindakan yang sesuai. Persepsi informan terhadap kesalahan medik, tipe-tipe kesalahan medik dan sumber-sumber kesalahan medik dan upaya pencegahan kesalahan medik cukup baik didasari atas pengalaman informan.

Ditinjau dari segi manajemen pengawasan dan pelaksanaan program keselamatan pasien di Unit Gawat Darurat RS "X" belum berjalan secara optimal, terbukti dari belum adanya laporan kesalahan medik ke Tim Manajemen Risiko, laporan insiden di ruangan tidak tersedia, adanya sikap "takut" apabila melaporkan kesalahan medik yang terjadi di ruangan karena belum adanya jaminan bahwa yang melakukan kesalahan dan melaporkan kesalahan tidak akan dikenakan sanksi, dan kurangnya pemahaman petugas mengenai kasus ataupun kesalahan yang harus dilaporkan. 
Kontroversi pendapat antara informan mengenai sikap dan tindakan yang diambil pimpinan di Unit Gawat Darurat RS "X" tersebut dalam mengantisipasi kejadian kesalahan medik. Adanya miskomunikasi antar petugas kesehatan di Unit Gawat Darurat RS "X" dengan pasien, dan miskomunikasi antara dokter dan perawat terutama dalam pemberian instruksi dan tindakan yang diambil. Faktor kerja sama tim masih kurang memadai dan masalah komunikasi baik komunikasi tertulis dalam bentuk instruksi tertulis di rekam medik yang kurang lengkap, maupun komunikasi lisan antara petugas dengan pasien atau keluarga pasien, dan antar sesama petugas di Unit Gawat Darurat RS "X". Sistem rujukan pasien di Unit Gawat Darurat RS "X” kurang baik sehingga menyulitkan keluarga pasien.

Fasilitas pelayanan gawat darurat di Unit Gawat Darurat RS "X" belum lengkap. Seperti alat monitor, ventilator dan alat pemantauan intensif untuk observasi pasien yang memerlukan intermediate care jumlahnya masih terbatas. Ruangan RS "X" sangat terbatas yaitu tidak memiliki ruangan observasi, ruangan tindakan resusitasi, ruangan tindakan persalinan. Hal ini menyebabkan ketidaknyamanan petugas kesehatan yang bekerja di unit tersebut. Berdasarkan hasil telaah dokumen di ruangan Unit Gawat Darurat RS "X" dokumen yang terdapat di unit tersebut adalah dokumen laporan harian, catatan perawat untuk kasus khusus, catatan dokter, formulir informed consent, dan Standar Operasional Prosedur (SOP), sedangkan laporan insiden (incident report) belum ada.

\section{Saran}

Rumah Sakit disarankan meningkatkan upaya keselamatan pasien dengan cara membuat kebijakan memberikan penghargaan kepada yang melaporkan kesalahan medik yang terjadi. Memperbaiki tata ruang Unit Gawat Darurat meliputi ruang observasi, ruang tindakan resusitasi. Melengkapi peralatan penanggulangan pasien gawat darurat, meliputi peralatan bantuan monitor, ventilator dan pemantauan intensif. Tim Manajemen Risiko disarankan meningkatkan pengawasan pelaksanaan program keselamatan pasien. Membuat panduan memudahkan staf untuk melapor. Menyediakan dan mengembangkan sistem pelaporan insiden klinis dengan menerapkan budaya tidak mencaricari kesalahan. Bekerja sama dengan rumah sakit untuk memudahkan petugas melakukan rujukan. Bagi Pimpinan Unit Gawat Darurat disarankan meningkatkan upaya pencegahan pada tingkat operasional pelayanan antara lain dengan meningkatkan peran serta petugas dalam pelaporan insiden klinis, mengembangkan budaya tidak mencari kesalahan, memberikan reward petugas yang melaporkan kesalahan medik. Melakukan refreshing keilmuan. Meningkatkan kapasitas pelayanan antara lain: meningkatkan keterampilan resusitasi, komunikasi antar tim, membuat pencatatan, mengarahkan petugas, bertukar pikiran.

\section{Daftar Pustaka}

1. Institute of Medicine. Crossing the quality chasm. Washington D.C: National Academy Press; 2001.

2. Kohn LT. To err is human: building a safer health system. Institute of Medicine. Washington D.C: National Academy Press; 2000.

3. Oyebode F. Clinical errors and medical negligence. Advances in Psychiatric Treatment. 2006;12: 221-7.

4. Frey B, Kehrer B, Losa M, Braun H, Berweger L, Micallef J, et al. Comprehensive critical incident monitoring in a neonatal-pediatric intensive care unit: experience with the system approach. Intensive Care Med. 2000; 26 (1): 8-10.

5. Valentin A, Capuzzo M, Guidet B, Moreno RP, Dolanski L, Bauer P, et al. Patient safety in intensive care: result from the multinational Sentinel Events Evaluations (SEE) study. Intensive Care Med. 2006; 32 (10): 1591-8.

6. Scales DC, Dainty K, Hales B, Pinto R, Fowler RA, Adhikari NK, et al. An innovative telemedicine knowledge translation program to improve quality of care in intensive care units: protocol for a cluster randomized pragmatic trial. Implement Sci. 2009; 16: 4-5.

7. Komite Keselamatan Pasien Rumah Sakit (KKP-RS). Buku pedoman keselamatan pasien. Jakarta: Direktorat Jenderal Pelayanan Medik Departemen Kesehatan RI; 2005.

8. Leape L. Peventing medical injury. Quall Rev Bull. 1993; 19(5): 144-9. 